\title{
Air and fuel supercharge in the performance of a diesel cycle engine
}

\author{
Marcelo Silveira de Farias $^{1}$ José Fernando Schlosser ${ }^{2}$ Alfran Tellechea Martini' \\ Gustavo Oliveira dos Santos $^{2}$ Javier Solis Estrada ${ }^{3}$
}

'Departamento de Ciências Agronômicas e Ambientais (DCAA), Universidade Federal de Santa Maria (UFSM), Campus Frederico Westphalen, 98400-000, Frederico Westphalen, RS, Brasil. E-mail: silveira_farias@hotmail.com. Corresponding author.

${ }^{2}$ Departamento de Engenharia Rural (DER), Centro de Ciências Rurais (CCR), Universidade Federal de Santa Maria (UFSM), Santa Maria, RS, Brasil. ${ }^{3}$ Distribuidor Oficial John Deere, IPESA S.A.C, Lima, Peru.

\begin{abstract}
This paper aimed to evaluate the performance of a Diesel cycle engine, changing the configurations for the air and fuel supply system. Variables analyzed were torque, power, specific fuel consumption and thermal efficiency in four different engine configurations (aspirated, aspirated + service, turbocharged + service and turbocharged). For that, there were dynamometer experiments by power takeoff of an agricultural tractor. The experimental outline used was entirely randomized, in a bifatorial design with three repetitions. Results indicated that the engine supercharge, compared to its original configuration, provided a significant increase of torque and power. Only the addition of turbo does not caused a significant effect in the engine performance. Application of turbocharger provides an improvement in the burning of the air/fuel mixture, which favors the increase of engine power and; consequently, reduced the specific fuel consumption. Key words: agricultural tractor, turbocharger, injection pump, fuel consumption.
\end{abstract}

Sobrealimentação de ar e combustível no desempenho de um motor ciclo Diesel

RESUMO: Este trabalho teve como objetivo avaliar o desempenho de um motor ciclo Diesel, alterando a configuração do sistema de alimentação de ar e de combustivel. As variáveis analisadas foram torque, potencia, consumo especifico de combustivel e eficiência térmica em quatro diferentes configurações do motor (aspirado, aspirado + serviço, turboalimentado + serviço e turboalimentado). Para isso, foram realizados experimentos dinamométricos por meio da tomada de potência de um trator agrícola. O delineamento experimental utilizado foi inteiramente casualizado, em desenho bifatorial com três repetições. Os resultados indicam que, a sobrealimentação do motor, em relação à configuração original, proporciona aumento significativo do torque e potência. Somente a adição de turbo não causa efeito significativo no desempenho do motor. A aplicação do turbocompressor proporciona melhoria na queima da mistura ar/combustivel, o que favorece o aumento da potência do motor e, consequentemente, reduz o consumo especifico de combustivel.

Palavras-chave: trator agrícola, turbocompressor, bomba injetora, consumo de combustivel.

\section{INTRODUCTION}

One of the main methods to increase engine power is the supercharging of air using a centrifugal compressor of turbocharger type. This system takes the energy from the exhaust gases to move one turbine, installed at the entrance of the air intake system of the engine. This allows a greater amount of air to enter the cylinder (KARABEKTAS, 2009).

Currently, the Diesel cycle engine manufacturers for the agricultural sector frequently use supercharging by turbocharger to obtain higher power. According to MUÑOZ \& PAYRI (1984) this trend is suitable for medium and high power engines.
Below this power, for aspirated engines, there are specialized companies that make kits available for the supercharging of air, and those kits are installed in engines of new and used tractors as requested by the users. This practice provided an increase in the engine power at a low cost, and that resulted in a good cost-effective ratio, since the kits are made to introduce in the cylinder an amount of air that is higher to the amount corresponding to natural aspiration. By doing that, one gets more power at the same displacement (GIACOSA, 1980; MÁRQUEZ, 2012). According to RAKOPOULUS et al. (2011), engine speeds have a direct relation to the volume of air admitted, altering the quality of the air and fuel mixture. 
To have significant gains of engine power, besides adding the kit, it is also necessary to increase the volume of fuel injected in the cylinder (SIMS et al., 1990). Also according to the authors, these modifications enable the reduction of the specific fuel consumption as a result of a better stoichiometric ratio, providing an increase in the thermal efficiency.

The Diesel cycle engines used in tractors present three types of fuel injection system, although there are others, which are individual pump, rotary pump and system with a complete injector unit (MIALHE, 1980). There are also injection systems with electronic control (that control those pumps electronically), and systems with a pressure tank. Those different configurations of the air and fuel supply system are known by the engine manufacturers and are frequently used to produce what is known as the engine family, aiming to meet a wide power range from the same engine block project (MÁRQUEZ, 2012).

As an example of engine family, it can be observed in the reports (1938, 1837C and 1939), published by the official tests Station of Nebraska, in 2009, that the New Holland tractors, models T2330, T2410 and T2420 are equipped with the same engine (ISM Diesel), but the first one is aspirated while the others are turbocharged, performing $32.53,35.80$ and $38.46 \mathrm{~kW}$ of maximum power, respectively.

From the knowledge of the additional power provided by the different configurations in the engine supply systems, the user should take into account the tractor mass and, when necessary, change the mass/power ratio to adapt it to the agricultural operation. Besides, it is important to pay attention in order to avoid damages to the chassis, transmission components and engine cooling system (SIMS et al., 1990).

So, this paper aimed to evaluate the torque, power, fuel specific consumption and thermal efficiency of an agricultural engine, altering the configuration of the air and fuel supply system.

\section{MATERIALS AND METHODS}

We used an agricultural tractor by Massey Ferguson, model MF 4275, equipped with an engine with the following characteristics: Diesel cycle, four stroke, Perkins, model 1104A44 , with four cylinders, displaced volume of $4400 \mathrm{~cm}^{3}$ and natural aspiration. The fuel supply system holds a mechanical rotary injection pump by Delphi. According to information provided by the manufacturer, the torque and maximum engine power are $275 \mathrm{Nm}$ and $56 \mathrm{~kW}(75 \mathrm{hp})$, respectively, under the ISO TR 14396 standard.

In the experiment, to determine the values of torque $(\mathrm{Nm})$ and calculate the power $(\mathrm{kW})$ according to the engine speed through power take-off (PTO) of the tractor, the researchers used an electrical dynamometer brake by EGGERS, model PT 301 MES, with braking capacity of up to $5.800 \mathrm{Nm}$. The hourly fuel consumption was measured by an EGGERS flow meter, model FM3-100, which made it possible to determine the specific fuel consumption $\left(\mathrm{g} \mathrm{kWh}^{-1}\right)$. We collected performance data using the Power Control software by EGGERS, which manages the use of the dynamometer and flow meter.

From the data of specific consumption and lower calorific value of the fuel were obtained the values of the engine thermal efficiency, by means of equation 1, important to identify the behavior of the engine

Where: $T E=\left(\frac{3600}{(S F C \times L C V)}\right) \times 100$

TE - Thermal efficiency of the engine (\%);

SFC - Specific fuel consumption $\left(\mathrm{g} \mathrm{kWh}^{-1}\right)$;

LCV - Lower calorific value of the fuel $\left(42.295 \mathrm{kcal} \mathrm{kg}^{-1}\right)$.

Additionally, aiming to investigate the efficiency of the air/fuel mixture burn, we collected the values of oxygen $\left(\mathrm{O}_{2}\right)$ not used by the engine and the temperature of the pollutant gases. For that, the exhaust pipe was installed with a SAXON gas analyzer, model Infralyt ELD and a $\mathrm{k}$ type thermocouple.

There were interventions in the engine so we could establish the configuration factor of the air and fuel supply system; initially, the tractor's engine was assessed in its original manufacturing configuration (C1: Aspirated). Later on, with the help of a specialized technician, the injection pump was regulated in a test bench, where the Diesel flow or load of this device went from $67 \mathrm{ml}$ at $800 \mathrm{rpm}$ of the injection pump to $74 \mathrm{ml}$, that is, there was an increase of $10 \%$ of injected Diesel, and that determined the second configuration (C2: Aspirated + Service). To evaluate the effects of the turbocharger in the engine performance, it was necessary to install a kit to supercharge the air made by Master Power, model APL 240, that has an air intake pressure of 1.0bar, and it was installed after the service at the injection pump (C3: Turbocharged + Service). After the turbocharger was installed, for the last configuration evaluated, again the original flow of the injection pump was used (C4: Turbocharged).

Before initiating the experiment, aiming to reach an optimal working temperature and using the 
dynamometer brake, the engine was heated, imposing enough loads to reduce in $25 \%$ its maximum rotation for a period of 20 minutes. That being done, the assessment of the engine performance was based on the NBR ISO 1585 (1996) standard, that corresponds to the NBR ISO 5484 (1985) standard. Due to measurements of the tractor's PTO, a significant loss of power was considered by engine transmission until the PTO of $8 \%$ (MÁRQUEZ, 2012).

The dynamometer was set to perform the reading of data every time there was a decrease of $100 \mathrm{rpm}$ on engine speed from the first collection made from 2300 to $1100 \mathrm{rpm}$. The results analysis was run on the engine speed ranges of 2100 to $1300 \mathrm{rpm}$, where we find torque speed and maximum power for all configurations assessed.

For the statistical analysis, the research used a bifatorial design in which the following factors were assessed: configuration of the air and fuel supply system $(\mathrm{C} 1 ; \mathrm{C} 2 ; \mathrm{C} 3$ and; $\mathrm{C} 4)$ and engine speed $(1300,1400,1500,1600,1700,1800,1900$, 2000, and 2100rpm) in an experimental outline completely randomized with three repetitions. After that, with the help of the Sisvar software, version 5.3 by FERREIRA (2011), the data was submitted to an analysis of variance and to a Tukey test $(\mathrm{P} \leq 0.05)$.

\section{RESULTS AND DISCUSSION}

After the variance analysis of the performance results (torque, power, fuel specific consumption and thermal efficiency) for the four configurations of the air and fuel supply system assessed (Factor A) and for the different engine speeds (Factor B), the interaction of the variables mentioned above presented a significant difference.

Figures $1 \mathrm{a}$ and $1 \mathrm{~b}$ present the torque and engine power curves in function of speed, respectively. Those pictures demonstrated that the highest values were obtained with the engine at the C3 configuration (Turbocharged + Service). In addition, the results indicated that only with the addition of injected Diesel oil (C2: Aspirated + Service), were the values of torque and consequently the values of power higher comparing to the engine in its original configuration ( $\mathrm{C} 1$ : Aspirated) and at C4 configuration (Turbocharged).

When analyzing the torque in function of the engine speed (Table 1), it is possible to see that the results differ significantly in four groups, according to the engine configurations. The values of the maximum torque were obtained at a 1300rpm speed, where the highest result $(361.17 \mathrm{Nm})$ was obtained when the engine operated at a $\mathrm{C} 3$ configuration. With the addition of the turbocharger, this configuration was superior in $37.77 \mathrm{Nm}$ comparing to $\mathrm{C} 2$.

When compared to the engine in its original configuration, it is notable that the service done on the injection pump (C2) was more effective than the addition of only the turbocharger (C4), seeing that with $\mathrm{C} 2$ there was an increase of $13.36 \%$ in torque, while with $\mathrm{C} 4$ this increase was $7.59 \%$ (Table 2). Increase in the engine torque is directly related to the amount of fuel injected inside the cylinder (MIALHE, 1996).

From the torque and engine speed, we can calculated the power. When analyzing this variable, we can see the same trend observed for torque (Figure 1a). The highest power values (maximum power) were obtained at 2100rpm and they differ significantly for the four configurations of the air and fuel supply. On average, only the addition of a turbocharger $(\mathrm{C} 4)$ provided an increase in power of $3.27 \mathrm{~kW}(6.70 \%)$ compared to the $\mathrm{C} 1$ configuration (Table 2). In a supercharged engine, it is possible to obtain an air intake pressure of little more than 1.6bar, which, in terms of power, means an increase of $15 \%$ over the increase of an engine with natural aspiration (MÁRQUEZ, 2012).

After the increase of the Diesel oil flow (service in the injection pump) and addition of a turbocharger (C3), the gaining of power, at 2100rpm, was $13.17 \mathrm{~kW}(23.66 \%)$ compared to configuration C1 (Table 1). Through the studying the addition of a turbocharger and adjustment of the fuel injection pump in a Diesel cycle agricultural engine with natural aspiration and power of $63.1 \mathrm{~kW}$, SIMS et al. (1990) observed that after the service performed on the injection pump the engine reached $65.9 \mathrm{~kW}$ and after the addition of the turbocharger it reached $77.1 \mathrm{~kW}$, that is an increase of $22.2 \%$ compared to the original condition.

The specific consumption of fuel decreased as the power provided by the engine increased (Figure 1c). Those values, using the C3 configuration in the speeds assessed, were inferior compared to the other configurations (Table 1), and on average, it represented $5.82 \%$ of fuel economy compared to its initial condition (Table 2). The improvement in the specific consumption is of 5\%, and it can be slightly higher at the maximum power curve (full load test), as well as for the functioning of the engine under partial loads (GIACOSA, 1980). If the adjustment of the injection pump is not altered when installing the turbocharger, it is possible to reduce the fuel specific consumption in up to $20 \%$ (IMPERIAL, 1980). 

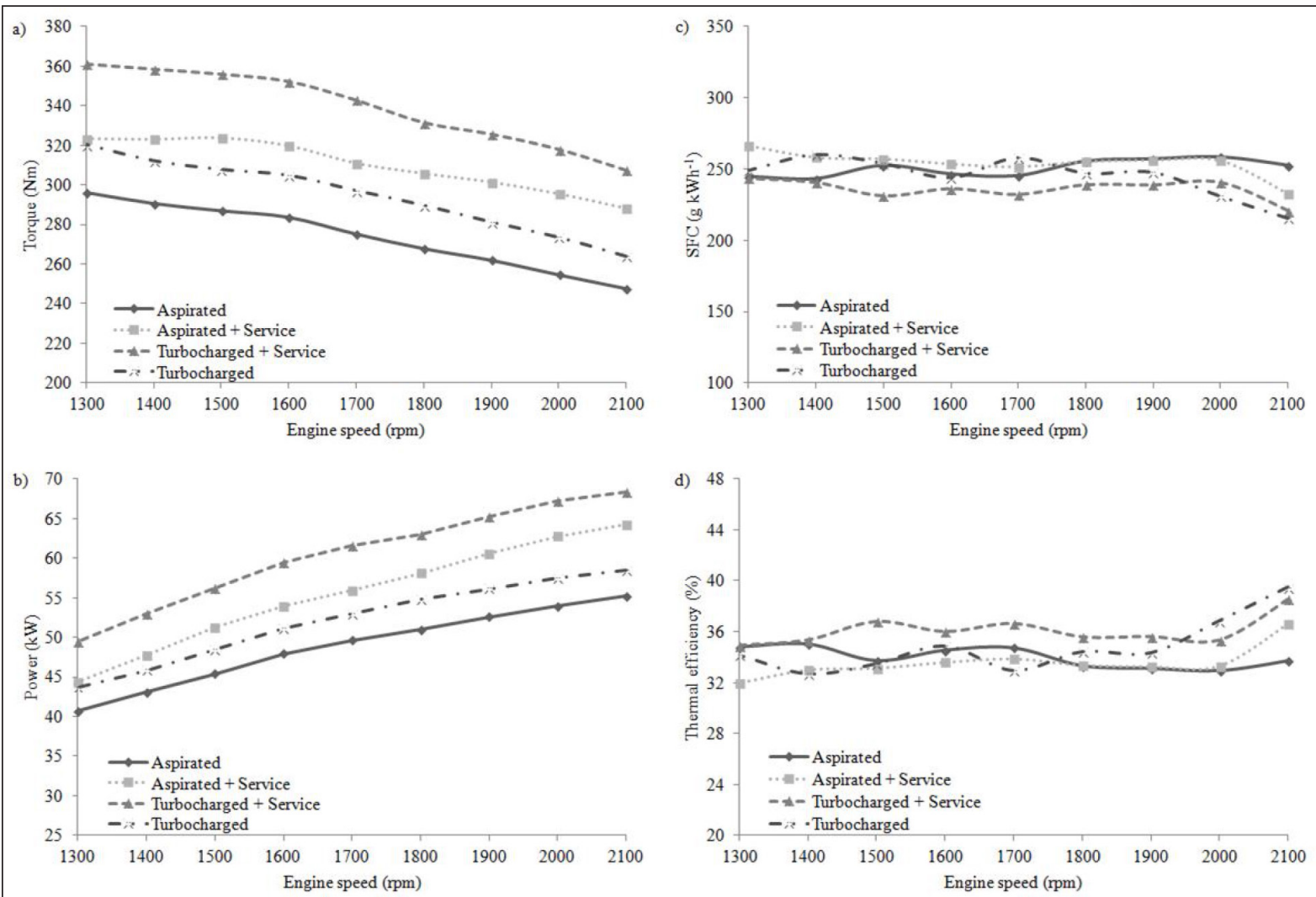

Figure 1 - Engine performance characteristic curves: a) torque; b) power; c) specific fuel consumption (SFC); d) thermal efficiency.

The best air/fuel ration mixed in the engine's combustion chamber can cause the reduction of the specific fuel consumption of the engine working at C3 configuration. The specific fuel consumption decreases due to the air temperature elevation and the increase of air mass inside the cylinder, ensuring the injected Diesel oil combustion. Thus, the best burn of this mixture favors the increase of engine power and; consequently, reduced the specific fuel consumption (KARABEKTAS, 2009).

Figure 1d demonstrated the thermal efficiencies for the four configurations assessed in function of the engine speed. Maximum values are observed in the speed range of 1400-1700rpm and 1500-1700rpm for C1 and C3, respectively. As shown on table 2, the engine thermal efficiency is improved with the addition of the turbocharger. In the case of agricultural and forest tractors, there were yields of up to $36 \%$ (PEÑA et al., 1993).

For the configurations of the engine with a turbocharger (C3 and $\mathrm{C} 4)$, the highest values of thermal efficiency were obtained, indicating the efficacy with which the combustion of cylinders happens (MIALHE, 1996). The thermal efficiency is simply the opposite of the specific consumption product and its heating value. Therefore, the highest thermal efficiency is related to the engine configuration that allows the lowest fuel specific consumption, taking into account a constant heating value (RAKOPOULOS et al., 2008).

Observing figure $2 \mathrm{a}$, one can see that the level of oxygen emitted by the engine increased as the rotation increased for all configurations studied, corroborating with data obtained by RAKOPOULUS et al. (2011), where they observed that high engine speeds improve the quality of the air and fuel mixture. This result is a consequence of a higher air volume inside the cylinders, and it is proportional to the engine displacement, its speed and the air density that reaches the cylinder (GIACOSA, 1980). Also, according to the author, the higher amount of air is one of the crucial factors for the good functioning of a Diesel engine, and that offers, among other things, the advantage of burning worse quality fuels than the ones used in the engines with natural aspiration because the 
Table 1 - Engine performance parameters (torque, power, specific fuel consumption and thermal efficiency) in different speeds for the four evaluated configurations.

\begin{tabular}{|c|c|c|c|c|c|c|c|c|c|}
\hline & 1300 & 1400 & 1500 & 1600 & 1700 & 1800 & 1900 & 2000 & 2100 \\
\hline $\mathrm{C} 1$ & $295.90^{d}$ & $290.40^{\mathrm{d}}$ & $286.73^{d}$ & $283.43^{d}$ & $275.00^{\mathrm{d}}$ & $267.67^{d}$ & $261.80^{d}$ & $254.47^{\mathrm{d}}$ & $247.50^{d}$ \\
\hline $\mathrm{C} 2$ & $323.40^{\mathrm{b}}$ & $323.03^{b}$ & $323.77^{b}$ & $319.73^{b}$ & $310.93^{b}$ & $305.80^{\mathrm{b}}$ & $301.40^{\mathrm{b}}$ & $295.53^{b}$ & $288.20^{\mathrm{d}}$ \\
\hline $\mathrm{C} 3$ & $361.17^{\mathrm{a}}$ & $358.60^{\mathrm{a}}$ & $356.03^{\mathrm{a}}$ & $352.37^{\mathrm{a}}$ & $342.83^{\mathrm{a}}$ & $331.47^{\mathrm{a}}$ & $325.60^{\mathrm{a}}$ & $317.90^{\mathrm{a}}$ & $307.27^{\mathrm{a}}$ \\
\hline $\mathrm{C} 4$ & $320.10^{c}$ & $312.03^{c}$ & $307.63^{c}$ & $304.70^{c}$ & $297.00^{c}$ & $289.67^{c}$ & $281.23^{c}$ & $273.53^{c}$ & $264.00^{c}$ \\
\hline Mean & 325.14 & 321.02 & 318.54 & 315.06 & 306.44 & 298.65 & 292.51 & 285.36 & 276.74 \\
\hline C.V. & $8.29 \%$ & $8.87 \%$ & $9.18 \%$ & $9.20 \%$ & $9.27 \%$ & $9.00 \%$ & $9.35 \%$ & $9.61 \%$ & $9.52 \%$ \\
\hline \multicolumn{10}{|c|}{ } \\
\hline $\mathrm{C} 1$ & $40.66^{\mathrm{d}}$ & $43.08^{\mathrm{d}}$ & $45.39^{d}$ & $47.92^{d}$ & $49.61^{\mathrm{d}}$ & $51.00^{\mathrm{d}}$ & $52.62^{d}$ & $53.90^{\mathrm{d}}$ & $55.18^{d}$ \\
\hline $\mathrm{C} 2$ & $44.40^{\mathrm{b}}$ & $47.74^{b}$ & $51.22^{\mathrm{b}}$ & $54.01^{\mathrm{b}}$ & $55.95^{\mathrm{b}}$ & $58.12^{\mathrm{b}}$ & $60.54^{\mathrm{b}}$ & $62.77^{\mathrm{b}}$ & $64.20^{\mathrm{b}}$ \\
\hline $\mathrm{C} 3$ & $49.39^{\mathrm{a}}$ & $52.91^{\mathrm{a}}$ & $56.25^{\mathrm{a}}$ & $59.47^{\mathrm{a}}$ & $61.53^{\mathrm{a}}$ & $63.03^{\mathrm{a}}$ & $65.27^{\mathrm{a}}$ & $67.17^{\mathrm{a}}$ & $68.35^{\mathrm{a}}$ \\
\hline $\mathrm{C} 4$ & $43.67^{\mathrm{c}}$ & $45.83^{c}$ & $48.44^{\mathrm{c}}$ & $51.15^{\mathrm{c}}$ & $52.98^{\mathrm{c}}$ & $54.74^{\mathrm{c}}$ & $56.14^{\mathrm{c}}$ & $57.46^{\mathrm{c}}$ & $58.45^{\mathrm{c}}$ \\
\hline Mean & 44.53 & 47.39 & 50.33 & 53.14 & 55.02 & 56.72 & 58.64 & 60.33 & 61.55 \\
\hline C.V. & $8.13 \%$ & $8.75 \%$ & $9.16 \%$ & $9.22 \%$ & $13.69 \%$ & $9.01 \%$ & $9.34 \%$ & $9.68 \%$ & $9.54 \%$ \\
\hline \multicolumn{10}{|c|}{ } \\
\hline $\mathrm{C} 1$ & $244.60^{\mathrm{b}}$ & $243.05^{\mathrm{b}}$ & $252.52^{\mathrm{a}}$ & $246.49^{\mathrm{ab}}$ & $245.16^{\mathrm{b}}$ & $255.62^{\mathrm{a}}$ & $257.21^{\mathrm{a}}$ & $258.65^{\mathrm{a}}$ & $252.65^{\mathrm{a}}$ \\
\hline $\mathrm{C} 2$ & $266.04^{\mathrm{a}}$ & $257.81^{\mathrm{a}}$ & $256.81^{\mathrm{a}}$ & $253.28^{\mathrm{a}}$ & $251.25^{\mathrm{ab}}$ & $254.95^{\mathrm{a}}$ & $255.84^{\mathrm{a}}$ & $255.54^{\mathrm{a}}$ & $232.46^{b}$ \\
\hline $\mathrm{C} 3$ & $243.90^{\mathrm{b}}$ & $240.91^{\mathrm{b}}$ & $231.26^{\mathrm{b}}$ & $236.39^{b}$ & $232.29^{c}$ & $239.24^{\mathrm{b}}$ & $239.08^{b}$ & $240.97^{b}$ & $220.63^{c}$ \\
\hline $\mathrm{C} 4$ & $249.13^{b}$ & $260.27^{\mathrm{a}}$ & $254.11^{\mathrm{a}}$ & $244.05^{\mathrm{ab}}$ & $258.19^{\mathrm{a}}$ & $247.21^{\mathrm{ab}}$ & $247.85^{\mathrm{ab}}$ & $230.97^{b}$ & $215.58^{c}$ \\
\hline Mean & 250.91 & 250.51 & 248.68 & 245.05 & 246.72 & 249.26 & 249.99 & 246.54 & 230.33 \\
\hline C.V. & $4.12 \%$ & $3.97 \%$ & $4.72 \%$ & $2.84 \%$ & $4.46 \%$ & $3.09 \%$ & $3.35 \%$ & $5.24 \%$ & $7.15 \%$ \\
\hline \multicolumn{10}{|c|}{ - } \\
\hline $\mathrm{C} 1$ & $34.82^{\mathrm{a}}$ & $35.03^{\mathrm{a}}$ & $33.71^{\mathrm{b}}$ & $34.53^{\mathrm{ab}}$ & $34.72^{\mathrm{b}}$ & $33.30^{\mathrm{b}}$ & $33.10^{\mathrm{b}}$ & $32.91^{\mathrm{b}}$ & $33.69^{c}$ \\
\hline $\mathrm{C} 2$ & $31.99^{\mathrm{b}}$ & $33.02^{\mathrm{b}}$ & $33.15^{b}$ & $33.61^{b}$ & $33.88^{b c}$ & $33.39^{\mathrm{b}}$ & $33.29^{\mathrm{b}}$ & $33.31^{\mathrm{b}}$ & $36.63^{b}$ \\
\hline $\mathrm{C} 3$ & $34.91^{\mathrm{a}}$ & $35.34^{\mathrm{a}}$ & $36.83^{\mathrm{a}}$ & $36.01^{\mathrm{a}}$ & $36.65^{\mathrm{a}}$ & $35.58^{\mathrm{a}}$ & $35.61^{\mathrm{a}}$ & $35.32^{\mathrm{a}}$ & $38.58^{\mathrm{a}}$ \\
\hline $\mathrm{C} 4$ & $34.18^{\mathrm{a}}$ & $32.71^{b}$ & $33.50^{\mathrm{b}}$ & $34.93^{\mathrm{ab}}$ & $33.01^{\mathrm{c}}$ & $34.44^{\mathrm{ab}}$ & $34.39^{\mathrm{ab}}$ & $36.86^{\mathrm{a}}$ & $39.51^{\mathrm{a}}$ \\
\hline Mean & 33.97 & 34.03 & 34.30 & 34.77 & 34.57 & 34.18 & 34.10 & 34.60 & 37.11 \\
\hline C.V. & $4.01 \%$ & $3.97 \%$ & $4.97 \%$ & $2.86 \%$ & $4.50 \%$ & $3.13 \%$ & $3.39 \%$ & $5.32 \%$ & $6.93 \%$ \\
\hline
\end{tabular}

*Means followed by the same letter in the column do not differ by the Tukey test at $5 \%$ error probability.

higher the air intake volume, the easier it is to obtain total combustion of the fuel load.

In both engine configurations that use the turbocharger ( $\mathrm{C} 3$ and $\mathrm{C} 4)$, the amount of oxygen it emits is higher when compared to the configurations of the engine without a turbo. These results prove the good functioning of the system, seeing that the supercharge enables the introduction in the cylinders and, consequently, the emission of an air mass that is superior and which can be obtained with natural aspiration (MÁRQUEZ, 2012).

Figure $2 \mathrm{~b}$ presents the behavior of exhaust gases temperature in function of engine speeds. The maximum temperatures of the gases measured

Table 2 - Average values of the engine performance variables and its variation $(\Delta)$ regarding configuration $\mathrm{C} 1$ (aspirated engine).

\begin{tabular}{lcccccccc}
\hline & Torque $(\mathrm{Nm})^{*}$ & $\Delta(\%)$ & Power $(\mathrm{kW})^{*}$ & $\Delta(\%)$ & ${\text { SFC }\left(\mathrm{g} \mathrm{kWh}^{-1}\right)^{*}}^{*} \Delta(\%)$ & T.E. $(\%)^{*}$ & $\Delta(\%)$ \\
\hline $\mathrm{C} 1$ & $273.65^{\mathrm{d}}$ & 0.00 & $48.82^{\mathrm{d}}$ & 0.00 & $250.66^{\mathrm{a}}$ & 0.00 & $33.98^{\mathrm{c}}$ & 0.00 \\
$\mathrm{C} 2$ & $310.20^{\mathrm{b}}$ & 13.36 & $55.44^{\mathrm{b}}$ & 13.56 & $253.77^{\mathrm{a}}$ & 1.24 & $33.59^{\mathrm{c}}$ & -1.15 \\
$\mathrm{C} 3$ & $339.25^{\mathrm{a}}$ & 23.97 & $60.37^{\mathrm{a}}$ & 23.66 & $236.07^{\mathrm{c}}$ & -5.82 & $36.09^{\mathrm{a}}$ & 6.21 \\
$\mathrm{C} 4$ & $294.43^{\mathrm{c}}$ & 7.59 & $52.09^{\mathrm{c}}$ & 6.70 & $245.26^{\mathrm{b}}$ & -2.15 & $34.84^{\mathrm{b}}$ & 2.53 \\
\hline
\end{tabular}

${ }^{*}$ Means followed by the same letter in the column do not differ by the Tukey test at $5 \%$ error probability. 

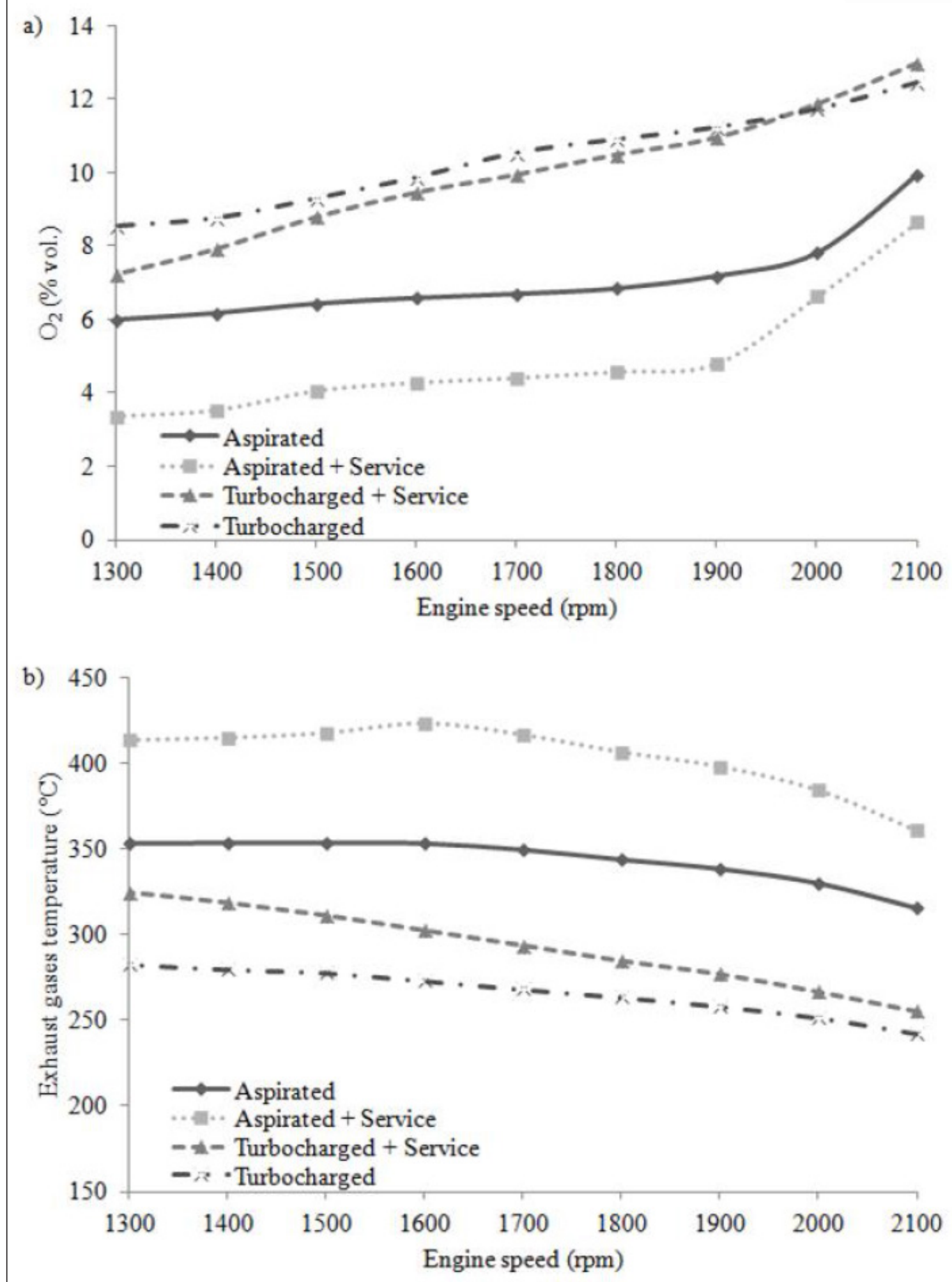

Figure 2 - a) Oxygen $\left(\mathrm{O}_{2}\right)$ and b) exhaust gases temperature emitted by the engine for the four configurations evaluated. 
for configurations $\mathrm{C} 1, \mathrm{C} 2, \mathrm{C} 3$ and $\mathrm{C} 4$ were 353.00 ; $422.67 ; 324.33$; and $282.67^{\circ} \mathrm{C}$, respectively. One can observe that these temperatures happened close to the engine maximum torque rotations. Considering the exhaust gases temperature behavior, there is an increase in the temperature when the loads applied to the engine are higher (AGARWAL et al., 2007).

The improved combustion due to the additional presence of oxygen and fuel after the addition of the turbocharger and the increase of Diesel oil flow can be the reason for the significant reduction of exhaust gases temperature (SIMS et al., 1990). At the peak of the maximum engine power, the temperature of the gases in the $\mathrm{C} 3$ configuration was $255.33^{\circ} \mathrm{C}$, which increased in a linear way to $324.33^{\circ} \mathrm{C}$ with the increase of the engine torque.

\section{CONCLUSION}

The addition of a turbocharger in a Diesel cycle engine of an agricultural tractor is an acceptable method to increase its performance, if done according to the manufacturer's specifications.

The engine supercharge compared to its original configuration, provides a significant increase of torque and power. The greatest torque and power values occur in the configuration turbocharged + increment of $10 \%$ Diesel oil. Only the addition of turbo does not caused a significant effect in the engine performance.

The greatest thermal efficiency is directly associated with the engine configuration that provided a lower fuel specific consumption, represented by the configuration turbocharged + service.

\section{ACKNOWLEDGEMENTS}

The authors are grateful to the Conselho Nacional de Desenvolvimento Científico e Tecnológico (CNPq) for research productivity scholarship of the second author. Also to the Itaimbé Máquinas dealership by the availability of agricultural tractor used in this work and specialized technician.

\section{REFERENCES}

ABNT NBR 5484. Motores alternativos de combustão interna de ignição por compressão (Diesel) ou ignição por centelha (Otto) de velocidade angular variável -Ensaio. Rio de Janeiro, 1985. $8 \mathrm{p}$.

ABNT NBR ISO 1585. Veículos rodoviários - Código de ensaio de motores - Potência líquida efetiva. Rio de Janeiro, 1996. 9p.
AGARWAL, A. Biofuels (alcohols and biodiesel) applications as fuels for internal combustion engines. Progress in Energy and Combustion Science, v.33, n.3, p.233-271, June 2007. Available from: <http://www.sciencedirect.com/science/article/ pii/S0360128506000384> . Accessed: Jul. 12, 2016. doi: 10.1016/j. pecs.2006.08.003.

FERREIRA, D.F. Sisvar: a computer statistical analysis system. Ciência e Agrotecnologia, v.35, n.6, p.1039-1042, Nov./Dec. 2011. Available from: <http://www.scielo.br/pdf/cagro/v35n6/ a01v35n6.pdf>. Accessed: Jul. 12, 2016. doi: 10.1590/S141370542011000600001

GIACOSA, D. Motores endotérmicos. 3.ed. Espanha: Dossat, 1980. 752p.

IMPERIAL, J.M. Turbo: sobrealimentação de motores rápidos. Lisboa: Cetop, 1980. 230p.

KARABEKTAS, M. The effects of turbocharger on the performance and exhaust emissions of a diesel engine fuelled with biodiesel. Renewable Energy, v.34, n.4, p.989-993, Apr. 2009. Available from: <http://www.sciencedirect.com/science/article/ pii/S0960148108003133>. Accessed: Jul. 11, 2016. doi: 10.1016/j. renene.2008.08.010.

MÁRQUEZ, L. Tractores agrícolas: tecnología y utilización. Espanha: B\&H Grupo Editorial, 2012. 844p.

MIALHE, L.G. Máquinas motoras na agricultura. São Paulo: EDUSP/USP, 1980. 289p.

MIALHE, L.G. Máquinas agrícolas: ensaios e certificação. Piracicaba, SP: Fundação de Estudos Agrários Luiz de Queiroz, 1996. 722p.

MUÑOZ, M.; PAYRI, F. Motores de combustión interna alternativos. Valencia, ES: Servicio de publicaciones de la Universidad Politécnica de Valencia, 1984. 725p.

PEÑA, S.V. et al. Los tractores en la explotación forestal. Madrid: Mundi-Prensa, 1993. 150p.

RAKOPOULOS, D.C. et al. Effect of ethanol - Diesel fuel blends on the performance and emissions of heavy duty DI Diesel engine. Energy Conversion and Manage, v.49, n.11, p.3155-3162, Nov. 2008. Available from: <http://www.sciencedirect.com/science/ article/pii/S0196890408002227>. Accessed: Jul. 12, 2016. doi: 10.1016/j.enconman.2008.05.023.

RAKOPOULUS, C.D. et al. Study of turbocharged diesel engine operation, pollutant emissions and combustion noise radiation during starting with bio-diesel or $n$-butanol diesel fuel blends. Applied Energy, v.88, n.11, p.3905-3916, Nov. 2011. Available from: <http:// www.sciencedirect.com/science/article/pii/S0306261911002212>. Accessed: Dec. 14, 2016. doi: 10.1016/j.apenergy.2011.03.051.

SIMS, R.E.H. et al. Turbocharging of an agricultural tractor engine. Journal of Agricultural Engineering Research, v.47, p.177-186, Sept./Dec. 1990. Available from: <http://www.sciencedirect.com/ science/article/pii/002186349080039W>. Accessed: Jul. 11, 2016. doi: 10.1016/0021-8634(90)80039-W. 